NASA Technical Memorandum 106808

AIAA-95-6146

\title{
Operating Capability and Current Status of the Reactivated NASA Lewis Research Center Hypersonic Tunnel Facility
}

Scott R. Thomas, Charles J. Trefny, and William D. Pack

Lewis Research Center

Cleveland, Ohio

Prepared for the

Sixth International Aerospace Planes and Hypersonics Technologies Conference sponsored by the American Institute of Aeronautics and Astronautics Chattanooga, Tennessee, April 3-7, 1995

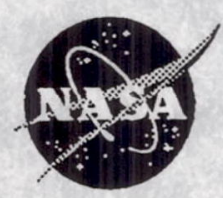

National Aeronautics and Space Administration 


\title{
OPERATING CAPABILITY AND CURRENT STATUS OF THE REACTIVATED NASA LEWIS RESEARCH CENTER HYPERSONIC TUNNEL FACILITY
}

\author{
Scott R. Thomas, Charles J. Trefny, William D. Pack \\ National Aeronautics and Space Administration \\ Lewis Research Center \\ Cleveland, Ohio 44135
}

\begin{abstract}
$\underline{\text { Abstract }}$
The NASA Lewis Research Center's Hypersonic Tunnel Facility (HTF) is a free-jet, blowdown propulsion test facility that can simulate up to Mach-7 flight conditions with true air composition. Mach-5, -6 , and -7 nozzles, each with a 42-in. exit diameter, are available. Previously obtained calibration data indicate that the test flow uniformity of the HTF is good. The facility, without modifications, can accommodate models approximately $10 \mathrm{ft}$ long. The test gas is heated using a graphite core induction heater that generates a nonvitiated flow. The combination of cleanair, large-scale, and Mach-7 capabilities is unique to the HTF and enables an accurate propulsion performance determination.
\end{abstract}

The reactivation of the HTF, in progress since 1990, includes refurbishing the graphite heater, the steam generation plant, the gaseous oxygen system, and all control systems. All systems were checked out and recertified, and environmental systems were upgraded to meet current standards. The data systems were also upgraded to current standards and a communication link with NASA-wide computers was added. In May 1994, the reactivation was complete, and an integrated systems test was conducted to verify facility operability. This paper describes the reactivation activities, the facility status, the operating capabilities, and specific applications of the HTF.

\section{Introduction: Facility Capabilities and Operation}

The NASA Lewis Research Center's Hypersonic Tunnel Facility (HTF), located at the Plumbrook Station, is a blowdown, nonvitiated free-jet facility capable of testing large-scale propulsion systems at Mach numbers up to 7 . Hypersonic engines and models typically up to $10 \mathrm{ft}$ in length and $2 \mathrm{ft}$ in diameter can be tested. Major features and an operating map of the HTF are shown in Fig. 1. The facility was completed as a hypersonic tunnel in 1971. From
1971 to 1974 a facility test flow calibration, ${ }^{1}$ followed by extensive testing of the hypersonic research engine (HRE), ${ }^{2}$ was conducted at the HTF. As shown by the calibration data in Fig. 2, the test flow uniformity of the HTF is good. In 1974 , as a result of decreased activity in hypersonics, the HTF was put into a standby mode. In 1986 a reactivation study was conducted for the facility. ${ }^{3}$ Reactivation was initiated in 1990 and has now been completed, culminating in an integrated systems test in May 1994.

Illustrations of the major HTF components are presented in Figs. 3 and 4. The energy source is the graphite induction nitrogen heater, which can supply nitrogen up to $130 \mathrm{lb} / \mathrm{sec}$ at initial conditions of $4500^{\circ} \mathrm{F}$ and $1200 \mathrm{psia}$. Nitrogen is supplied to the heater from a railcar. The hot nitrogen from the heater flows through graphite-lined, water-cooled piping and an isolation valve into a watercooled mixer. Oxygen and diluent nitrogen are added to the hot nitrogen through an injection flange upstream of the mixer to produce the simulated air with the desired enthalpy. This produces a test flow with true temperature, composition, and altitude simulation. A different injection flange is used with each of the three interchangeable, axisymmetric, Mach-5, -6, and -7 nozzles to optimize jet penetration and mixing. The operating range and maximum run times with each of these nozzles installed are shown in Table 1. The test section free-jet length can be varied to a maximum of about $10 \mathrm{ft}$ by adjusting the tapered diffuser inlet position. The facility nozzle and the diffuser exhaust duct penetrate the chamber wall; inflatable seals are used around the interfaces. A hydraulically operated model injection system is available to swing a test model in an arc from the side, translate the model axially by up to 30 in., and provide an angle of attack of up to $5^{\circ}$. The exhaust system includes a supersonic diffuser, a combined subsonic diffuser and spray cooler, and a single-stage steam ejector. Steam is supplied through a 30 -in.-diameter steam line to the ejector from a boiler house located approximately $3000 \mathrm{ft}$ away.
Copyright (C) by the American Institute of Aeronautics and Astronautics, Inc. No copyright is asserted in the United States under Title 17, U.S. Code. The U.S. Government has a royalty-free license to exercise all rights under the copyright claimed herein for Government purposes. All other rights are reserved by the copyright owner. 
Prior to facility operation, the heater and supporting systems are energized and the heater is brought up to the required operating temperature. The steam plant is brought on line and all accumulators are charged to 500 psig. The cooling water system, main nitrogen systems, hydraulic systems, flow computer, data systems, and test matrix sequencer are set up and calibrated; all instrumentation is checked out. The nitrogen railcar, the oxygen system, and the sequencer programmable logic controllers (PLC's) are set up. The steam line is preheated using steam supplied directly from the boilers. A 2.5-psig purge is present on the graphite heater at all times. Immediately prior to facility operation, the steam line is brought up to 200 psig at the ejector supply station. The chamber vent valve is closed, the cooling water flow is established, a 2.5-psig purge is placed on the hot train components, and the radiation shutter valve is opened. The main steam valve is subsequently opened and the ejector flow is established. When the test chamber pressure drops to $1.5 \mathrm{psia}$, the heater operating pressure is ramped to the operating point, and the spray cooler is brought on line. The flow computer controls the gaseous nitrogen $\left(\mathrm{N}_{2}\right)$ and oxygen $\left(\mathrm{O}_{2}\right)$ systems to maintain heat, mixture, and pressure for the duration of the run. At the termination of the run, the facility systems progress through an orderly shutting down of the $\mathrm{N}_{2}$ and $\mathrm{O}_{2}$ systems, depressurizing the heater, establishing a purge on the hot train, shutting down the spray cooler, and establishing the purge on the heater. The radiation shutter valve is then closed, and all cooling water is stopped. Finally, the steam ejector is shut off and the chamber vent valve opened.

The HTF facility is unique because it combines the capabilities of large scale (42-in. nozzle exit diam) and Mach-7 enthalpy clean air. Heating techniques used to provide highenthalpy gas for hypersonic propulsion testing include electric arcs, combustion heating (often using hydrogen or methane fuels with oxygen replenishment), or storage and/or pebble-bed heaters. The use of an electric arc heater results in air dissociation and the generation of significant amounts of nitrogen oxides. In combustion heaters, the net flow constituents are a function of the fuel used; for example, with a hydrogen burner, $\mathrm{H}_{2} \mathrm{O}$ is a primary contaminant; with a methane heater, a combination of both $\mathrm{H}_{2} \mathrm{O}$ and $\mathrm{CO}_{2}$ are the primary contaminants. Because of these contaminants, the combustion characteristics in a ramjet or scramjet engine have the potential to be significantly different from the results obtained in clean air. Propulsion testing in a facility with the correct flow constituents, as with a storage heater, most closely represents the actual flight condition and minimizes the potential errors between ground test results and flight performance.

\section{$\underline{\text { Reactivation Summary }}$}

The reactivation work included the following: rebuilding the graphite heater; dismantling and rebuilding the steam plant; changing the oxygen system design; and refurbishing the valves, pumps, and tanks of the oxygen, nitrogen, and water system. Also included was the recertification of high pressure systems and the rehabilitation of electrical, instrumentation, and control systems. During rehabilitation, all systems were analyzed, inspected, and tested to ASME Boiler and Pressure Vessel Code and ANSI/ASME Power Piping Codes by the Lewis Recertification manager. All pressure vessel and piping designs were reviewed and appropriate nondestructive examinations (NDE) were performed. An in-depth hazards analysis was performed on all risks. Steps were taken to reduce the risks to an acceptable level. The methodology of the hazards analysis was that of the Lewis Safety Manual and MIL-STD 882B.

\section{Description and Status of Main Tunnel Components}

\section{Graphite Induction Nitrogen Heater}

Figure 5 is a cutaway view of the nitrogen heater, which consists of a stacked array of 15 cylindrically shaped graphite blocks, $6 \mathrm{ft}$ in diameter and $2 \mathrm{ft}$ in height, with 1100 holes drilled through each block (Fig. 6) to enhance heat transfer. Hexagonal graphite block keys assure the proper alignment of the drilled holes, which increase in diameter from the bottom to the top block to maintain a constant velocity and to minimize the pressure drop through the stack. Current is passed through the water-cooled copper induction coils; a $180-\mathrm{Hz}$, single-phase, $750-\mathrm{V}$ supply ( $3 \mathrm{MW}$ ) is used to induce a magnetically coupled current in the outer diameter of the carbon graphite blocks to a depth of about 4 in. The graphite blocks are then heated as a result of their resistance to the induced current. Heating occurs slowly to reduce thermal stresses. The heat induced on the outer edge of the blocks then soaks by conduction to the center of the blocks. The stack of blocks is insulated with a 7-in.-thick layer of graphite felt and a 2-in.-thick silicon carbide tile shell to reduce heat loss to the outer components and the water-cooled pressure vessel. The heater core assembly is contained in a water-cooled steel pressure vessel that has a 4-in.-thick wall, a 9-ft 2-in. diameter, and a $40-\mathrm{ft}$ height. The copper induction heating coils and the heater vessel are cooled with demineralized water. The maximum conditions for the heater are $1200 \mathrm{psig}, 4500^{\circ} \mathrm{F}$, and $130 \mathrm{lb} / \mathrm{sec}$. 
During the reactivation, two of the graphite blocks were replaced and the carbon felt, which had deteriorated in the previous operation, was replaced with graphite felt. All the components were inspected and repaired as necessary. Repairs to the water-cooled induction heating coils included replacing the $\mathrm{O}$-rings with those of an improved design. The water-cooled pressure vessel was thoroughly inspected and hydropressure tested. It was recertified for its operating pressure of $1200 \mathrm{psig}$.

\section{High Pressure Main Gaseous Nitrogen}

The storage vessel for the high pressure gaseous nitrogen is a railroad tank car that was refurbished and recertified for a 4500-psig pressure rating with a total volume of $663000 \mathrm{SCF}$ (total mass of approx. $50000 \mathrm{lb}$ ). The railcar is recharged with gaseous nitrogen that is purchased from a local supplier or is supplied by a remotely located vaporizer system (installed during the reactivation to fill the railcar from a liquid nitrogen supply).

\section{Oxygen System}

A bottle farm supplies the oxygen that is blended at the mixer section with the hot nitrogen to make synthetic air. Six carbon steel bottles, each with an approximate volume of $425 \mathrm{ft}^{3}$, are rated for 2212-psig service. The oxygen is stored at $2000 \mathrm{psig}$, is delivered at $1000 \mathrm{psig}$, and has flow rates as high as $50 \mathrm{lb} / \mathrm{sec}$. The piping and tubing construction is stainless steel and Monel. The system is protected by relief devices, and all operations involving flowing gas are performed remotely. The system is charged by an on-site vaporizing system.

\section{$\underline{\text { Hot Train Components }}$}

After the nitrogen is heated by the induction storage heater, it passes through the facility components (as illustrated in Fig. 3): the hot tee, the radiation shutter valve, the diluent injection flange, the film cooling flange, and the mixer. The graphite-lined hot tee turns the flow from vertical to horizontal. The radiation shutter valve seals off the heater between test runs and allows a positive gaseous nitrogen purge pressure to be maintained on the heater during standby. If required, the diluent injection flange injects the oxygen and ambient temperature nitrogen to generate the simulated air at the proper stagnation conditions. For each test Mach number, there is a different flange that has the correct number of orifices with the required diameter to assure good mixing. The film cooling flange is a heat sink component placed to remove heat from the Oring seal on the mixer and inject cold nitrogen into the seal cavity to protect the seal. The mixer consists of an Inconel 718 cylindrical liner $5 \mathrm{ft}$ in length and $18 \mathrm{in}$. in diameter. The liner is water cooled and is separated from the external pressure shell by $\mathrm{O}$-ring seals. The flow then expands through one of the Mach-5, -6 , or -7 nozzles into the test section.

All hot train components were inspected and were refurbished, which included replacing the eroded carbon liner in the piping upstream of the shutter valve. All components were certified to a maximum operating pressure of 1200 psig.

\section{Facility Nozzles}

Three axisymmetric nozzles with nominal exit Mach numbers of 5, 6 and 7 are available for testing at the HTF. Each nozzle has an exit diameter of 42 in. The nozzles were fabricated using an electroforming process; the Mach-5 nozzle was completely formed from nickel; the Mach-6 and -7 nozzle throat sections were machined from zirconium copper forgings and were electroformed to nickel expansion sections. All three nozzles were inspected and are available for use.

Test Chamber, Model Injection System, and Thrust Mount Assembly

The test chamber (Fig. 3 ) is a domed cylindrical structure, $25 \mathrm{ft}$ in diameter and approximately $20 \mathrm{ft}$ in height, made of high-carbon steel. By a swinging action, an overhead carriage holds and positions the test article in the freejet stream. The model can also be translated up to 30 in. along the free-jet axis, and the thrust table can be hydraulically pivoted to a $5^{\circ}$ angle of attack. This model injection system and thrust table were designed to handle a test article of up to a $16000-\mathrm{lb}$ dead weight and an 8500-lb thrust load. The test chamber was inspected during the reactivation and was in good condition; it was not modified or upgraded. The model injection system and thrust mount assembly were not checked out and will require some refurbishment before being put into service.

\section{Exhaust System}

The exhaust system consists of the water-cooled supersonic diffuser, the heat sink subsonic diffuser, the spray cooler, and a single-stage steam ejector (Fig. 4). The steam-driven ejector is used to evacuate the test chamber to simulate altitude conditions over the free-jet operating envelope. The supersonic diffuser consists of a translatable, water-cooled, 55-in.-diameter inlet collection cone followed by a constant-diameter section, $30 \mathrm{ft}$ in length and $43 \mathrm{in}$. in diameter. The subsonic diffuser incorporates in-stream water spray nozzles designed to cool the exhaust gases to saturation temperature. The single-stage steam ejector uses a coaxial nozzle. The steam consumption for the ejector is $500 \mathrm{lb} / \mathrm{sec}$ at $130 \mathrm{psig}$. A 30 -in. gate valve in the steam 
supply piping acts as an on/off valve. The mixed flow exits to the atmosphere at $300^{\circ} \mathrm{F}$. All components of this system were checked out and were operated during the reactivation.

\section{$\underline{\text { Steam Supply System }}$}

This system includes a boiler house, five accumulators, and a steam supply line. The boiler house equipment consists of four boilers, each capable of supplying $25000 \mathrm{lb} / \mathrm{hr}$ of saturated steam at 500 psig to the five accumulators. The boilers are supported by fuel, feedwater, and control systems and by a 150-psig auxiliary steam boiler. The five accumulators can supply $584 \mathrm{lb} / \mathrm{sec}$ of saturated steam regulated to $150 \mathrm{psig}$. Each accumulator is capable of supplying $28900 \mathrm{lb}$ of steam when discharging from 500 to 200 psig. During the reactivation, only two of these boilers were refurbished and are now operational. One of the remaining boilers could be brought on-line with minimal investment, but the fourth boiler would require significant repair. All five accumulators were recertified and reinsulated; these are cylindrical and are $12 \mathrm{ft}$ in diameter, $53.5 \mathrm{ft}$ in length, and have 2:1 elliptical heads. A 30-in.diameter, 3000-ft. line supplies the steam to the HTF.

\section{Gaseous Hydrogen Heater}

The gaseous hydrogen heater is a pebble-bed electrical resistance heater capable of supplying up to $2.5 \mathrm{lb} / \mathrm{sec}$ of $\mathrm{GH}_{2}$ at $1200^{\circ} \mathrm{F}$ for $90 \mathrm{sec}$. This heater was not checked out during the reactivation but was operational when the facility was put into standby. The extent of the work required to put this heater back into service is uncertain; however, it is expected to be minimal.

\section{Gaseous Hydrogen System}

Hydrogen is supplied from high pressure bottle trailers at up to five stations to the hydrogen heater or directly to the test apparatus. This results in a total capacity of $35000 \mathrm{SCF}$ at $2400 \mathrm{psig}$. The gaseous hydrogen system was not refurbished during the reactivation but should require only minimal work. The design work was done on a hydrogen supply system for testing a scramjet engine such as the Langley Research Center parametric engine or the National Aero-Space Plane (NASP) engine concepts.

\section{Liquid Hydrogen Dewar System}

A 6000-gal, vacuum-jacketed, 2160-psig working pressure storage Dewar is available to store liquid hydrogen for use as a fuel. Currently in service, this Dewar is used as a high pressure demineralized cooling water supply vessel.

\section{Instrumentation and Controls}

The instrumentation and control systems include the gaseous nitrogen induction heater control, the sequence controller, the test matrix sequencer, the flow computer, and data acquisition system.

The gaseous nitrogen induction heater is controlled using dual-programmable logic controllers (PLC's) which provide automated control of the heat-up and cool-down operations. The heater is operated by a primary controller. If the primary controller fails, a hot standby feature that was incorporated in this installation will switch control of the heater to the redundant PLC. Manual controls are also available for operating the gaseous nitrogen heater.

The sequence control is also accomplished using dual PLC's that provide automated control of the test sequence, which includes starting the data recorders, establishing cooling water flow, opening the radiation shutter valve, opening the steam valve, pressurizing the heater, depressurizing the heater, closing the radiation shutter valve, and closing the steam valve. To provide backup control in the event of a primary PLC failure, the sequencer PLC has the same hot standby feature as the gaseous nitrogen heater controls.

The test matrix sequencer (TMS) is a personalcomputer-based controller. The TMS generates ramps and setpoints for the nitrogen supply valve and provides the ratio setpoints for the diluent nitrogen and oxygen valves via the flow computer. It has outputs to start and stop the ESCORT D and Masscomp data systems and the sequencer PLC.

The flow computer is an analog computer used to calculate and control nitrogen and oxygen flow through the gaseous nitrogen heater and mixer. It uses operational amplifiers to generate continuous setpoints and provides feedback monitoring for the oxygen valve and the diluent nitrogen valve, which supplies the mixer section of the hot tee. The flow computer also calculates the total flow through the heater and the hot tee and generates a shutdown signal to the test matrix sequencer, the sequencer PLC, and the flow valve controllers if the flow conditions do not meet specifications.

Facility and research parameters are recorded and monitored on an ESCORT D data acquisition system similar to that described in Ref. 4. ESCORT D can record up to 352 programmable data channels. A high-speed Masscomp data system with a series of ESP pressure modules is available for test article data acquisition. 
Low Pressure Demineralized Water System

The low pressure demineralized water system supplies cooling water to the nitrogen heater water jacket, the induction cooling coils, the capacitors, and parts of the hot train and hot tee. This system comprises two cooling loops: a primary closed-loop demineralized water system and a secondary domestic water cooling loop for removing heat from the demineralized water. The primary loop consists of a surge tank, low pressure boost pump, filter, heat exchanger, high pressure supply pump, valving and controls for the emergency water system, and associated piping. The secondary loop consists of a cooling tower, supply pump, heat exchanger, valving, and piping. Demineralized water is supplied to all cooling loops through a water softener and reverse osmosis demineralizer. Flow requirements for the primary cooling loop are $660 \mathrm{gal} / \mathrm{min}$ at $85 \mathrm{psia}$.

\section{High Pressure Demineralized Water Systems}

The high pressure demineralized water systems provide cooling water for the mixer, diffuser, nozzle, and test hardware. Three 6500-gal storage tanks and a 6000-gal LH Dewar loop are currently used for high pressure water storage. Cooling water for the mixer and diffuser is supplied from the first 6500 -gal storage tank by a pump rated at $1000 \mathrm{gal} / \mathrm{min}$ and $120 \mathrm{psig}$. Cooling water for the hypersonic nozzle is supplied from another 6500 -gal storage tank by a pump rated at $300 \mathrm{gal} / \mathrm{min}$ and $400 \mathrm{psig}$. The third 6500 -gal tank is available to supply cooling water for test hardware at $1200 \mathrm{gal} / \mathrm{min}$ and $400 \mathrm{psig}$. The 6000 -gal $\mathrm{LH}_{2}$ Dewar supplies up to $400 \mathrm{gal} / \mathrm{min}$ at $400 \mathrm{psig}$ for cooling the engine and $400 \mathrm{gal} / \mathrm{min}$ at $400 \mathrm{psig}$ for cooling the hot train components.

\section{Nitrogen Gas Purge and Valve Operator}

Nitrogen for system purging and valve actuation is supplied through a system of piping and regulator stations from a 70 000-SCF, 2500-psig bottle trailer nitrogen supply.

\section{$\underline{\text { Service Air }}$}

A 7.5-hp, 26-SCFM air compressor, located in the shop area, provides 100 -psig service air to the facility. A piping system routes the compressed air to various locations throughout the building.

\section{Domestic Water}

The domestic water system is also used as a backup cooling water supply for the nitrogen heater in the event that the primary low pressure demineralized water system fails. If a loss of flow in the primary low pressure demineralized water system should occur, this secondary cooling system automatically activates in a few seconds to protect the nitrogen heater from overheating. A supply flow rate of $660 \mathrm{gal}-\mathrm{min}$ is required for cooling the nitrogen heater.

\section{Auxiliary Safety Systems}

Various safety systems are in place in the test facility: fire detection equipment includes smoke detectors, pull boxes, and alarms; a low-oxygen warning system is in operation whenever nitrogen gas is used; ultraviolet detectors are used for fire detection during test operations; Scott Air Paks and personnel protective equipment are available during site operations.

\section{Results of Recent System Checkouts/Test Activity}

From mid 1993 to mid 1994, all systems were checked out, serviced if needed, and made operational. All gas supply systems were leak-checked, the valves were operated, and the control systems were verified. All major systems were individually operated to the greatest extent possible; for example, the steam ejector was brought on-line and used to pull a vacuum on the test cabin, and the graphite heater was brought up to an elevated temperature. In May 1994, an abbreviated integrated systems test (IST) was performed. Prior to the test, the graphite heater was brought to a temperature of approximately $3000 \mathrm{R}$, and the steam boilers were used to charge the five accumulators with saturated steam at $500 \mathrm{R}$ and $500 \mathrm{psia}$. Then, using the sequence controller, the steam ejector was first brought on-line to bring the test cabin to vacuum; then gaseous nitrogen was passed through the heater, hot train components, and nozzle, into the test chamber, and then exhausted to the atmosphere. Figure 7 shows the steam ejector in operation during the integrated systems test. This was a short-duration test relative to a normal run (approx $2 \mathrm{sec}$ versus approx $1 \mathrm{~min}$.) and included only the heater nitrogen flow (no diluent oxygen or nitrogen was added). This IST, however, verified that all facility systems would operate successfully together as designed.

\section{Current Resolutions of Past Operational Problems}

A previous operational problem of significant concern was the erosion of the carbon felt, the graphite lining in some of the hot train components, and, to a lesser extent, the graphite heater blocks. During testing of the HRE in 1971 to 1974, this erosion problem resulted in both a decreased temperature capability for the facility and significant visible carbon particulate levels, which caused a slight erosion of the HRE model. This result highlighted several concerns relative to the HTF's operational capability. The first issue was whether carbon particulates were a source of 
test flow contamination that could effect test results, particularly in a combustion experiment. Another issue was model erosion that could change the surface and leading edge properties. Continued facility operation with carbon erosion would be unacceptable. The erosion was attributed to water in the heater resulting from leaks in the watercooling coils or "flashback" from spray cooling in the ejector. The suspected leak path from the cooling coils was through single O-rings. During the rehabilitation, the $\mathrm{O}$ rings were all replaced, a second O-ring was added at each location, and the coils were leak-checked using a helium mass spectrometer. Also, the carbon felt insulation was replaced with graphite felt, which undergoes additional heat treatment during manufacturing and is more impervious to water. The potential for water flashback from the spray cooler was eliminated by modifying the shutdown sequence. This sequence now involves taking the spray cooler off-line while there is still flow in the test section and opening a test cabin vent. When the chamber reaches atmospheric pressure, a vent fan moves air into the chamber. During all system checkouts and the integrated systems test, there was no sign of water in the graphite heater or hot train. Therefore, it is expected that only minimal erosion of the graphite heater and hot train components will occur during operation. This will be verified during future testing, which will include gas sample surveys.

\section{Unique Value and Applications of HTF Capability}

The HTF is unique because of its combination of large scale and clean air. Results obtained in vitiated facilities are expected to require correction; however, the magnitude of this correction is unknown because of the absence of data. Tests in the HTF could resolve this critical issue. Design work has been completed for a system that will permit contaminants to be added to the HTF test flow, allowing tests with both clean and vitiated air. Thus, a direct examination of these contaminant effects on performance will be possible.

During scramjet engine flight tests, the number of measurements and test conditions is limited. Ground test data can provide the much more detailed information that is required to interpret the flight test results and allow refinement of the propulsion system. This process is complicated by any correction required for free-stream contamination. Data from a clean-air facility such as the HTF will not require any such correction, resulting in a more accurate assessment of the propulsion process. The HTF thus provides a critical capability for the research and development of ramjet/scramjet propulsion systems.

Facility nozzles for lower Mach numbers from Mach 2 to 5 could be fabricated and additional dilution air added to lower the test flow temperature to match the required flight conditions. The facility could also be modified to add a vitiated heater downstream of the mixer to provide near a Mach-10, direct-connect combustion test capability.

\section{$\underline{\text { Concluding Remarks }}$}

The NASA Lewis Hypersonic Tunnel Facility is a unique national asset because of the combination of large scale and clean air. The facility has been used for Mach-5, -6 , and -7 ramjet/scramjet engine testing. The HTF is again available for hypersonic propulsion testing after completion of an extensive reactivation, during which all systems were recertified and environmental systems were upgraded to meet current standards. The data systems were upgraded to current standards and a communication link with NASAwide computers was added. In May 1994 the reactivation was complete, and an integrated systems test was conducted to verify the facility operability. There is still work to be completed on the facility fuel system, model injection system, and propulsion test specific systems and requirements. The major effort, however, has been completed and the NASA Lewis Hypersonic Tunnel Facility is available to support the development of hypersonic propulsion systems for the $21^{\text {st }}$ century.

\section{References}

1. Cullom, R.R.; and Lezberg, E.A.: Calibration of Lewis Hypersonic Tunnel Facility at Mach 5, 6, and 7. NASA TN D-7100, 1972.

2. Andrews, Earl H.; and Mackley, Ernest A.: NASA's Hypersonic Research Engine Project: A Review. NASA TM-107759, 1994.

3. Haas, Jeffrey E.: Reactivation Study for NASA Lewis Research Center's Hypersonic Tunnel Facility. AIAA Paper 87-1886, June 1987 (NASA TM-89918).

4. Fronek, Dennis L.; Setter, Robert N.; Blumenthal, Philip Z.; and Smalley, Robert R.: A Distributed Data Acquisition System for Aeronautics Test Facilities. NASA TM-88961, 1987. 
TABLE 1.-UPPER AND LOWER LIMTTS OF HTF TEST FLOW CONDITIONS

\begin{tabular}{|c|c|c|c|c|c|c|c|c|c|}
\hline \multirow{2}{*}{$\begin{array}{c}\text { Mach } \\
\text { number }\end{array}$} & \multicolumn{5}{|c|}{ Nozzle } & \multicolumn{4}{|c|}{ Test section } \\
\hline & $\begin{array}{c}\text { Pressure, } \\
\text { psia }\end{array}$ & $\begin{array}{c}\text { Temper- } \\
\text { ature, } \\
\text { R }\end{array}$ & $\begin{array}{l}\text { Flow, } \\
\text { lb/sec }\end{array}$ & $\begin{array}{c}\text { Throat } \\
\text { diameter, } \\
\text { in. }\end{array}$ & $\begin{array}{c}\text { Exit } \\
\text { diameter, } \\
\text { in. }\end{array}$ & $\begin{array}{c}\text { Static } \\
\text { pressure, } \\
\text { psia }\end{array}$ & $\begin{array}{l}\text { Static } \\
\text { tempera- } \\
\text { ture, } \\
\text { R }\end{array}$ & $\begin{array}{c}\text { Altitude, } \\
\mathrm{ft}\end{array}$ & $\begin{array}{c}\text { Run } \\
\text { times, } \\
\text { sec }\end{array}$ \\
\hline 5 & $\begin{array}{l}410 \\
70.5\end{array}$ & $\begin{array}{l}2200 \\
2420\end{array}$ & $\begin{array}{l}189 \\
30.9\end{array}$ & $\begin{array}{l}7.2 \\
7.2\end{array}$ & 42 & $\begin{array}{c}0.74 \\
.118\end{array}$ & $\begin{array}{l}384 \\
428\end{array}$ & $\begin{array}{l}68 \times 10^{3} \\
108\end{array}$ & $\begin{array}{l}{ }^{a} 103 \\
b_{294}\end{array}$ \\
\hline 6 & $\begin{array}{r}1200 \\
144\end{array}$ & $\begin{array}{l}2965 \\
3310\end{array}$ & $\begin{array}{l}222 \\
25.4\end{array}$ & $\begin{array}{l}4.9 \\
4.9\end{array}$ & 42 & $\begin{array}{c}0.61 \\
.071\end{array}$ & $\begin{array}{l}390 \\
451\end{array}$ & $\begin{array}{l}72 \times 10^{3} \\
120\end{array}$ & $\begin{array}{r}a_{42} \\
b_{294}\end{array}$ \\
\hline 7 & $\begin{array}{r}1200 \\
430\end{array}$ & $\begin{array}{l}3830 \\
4190\end{array}$ & $\begin{array}{l}104 \\
36.19\end{array}$ & $\begin{array}{l}3.5 \\
3.5\end{array}$ & 42 & $\begin{array}{c}0.33 \\
.071\end{array}$ & $\begin{array}{l}412 \\
451\end{array}$ & $\begin{array}{l}93 \times 10^{3} \\
120\end{array}$ & $\begin{array}{r}a^{2} 90 \\
c_{180}\end{array}$ \\
\hline
\end{tabular}

${ }^{\mathrm{a}}$ Limited by maximum gas temperature change of $200^{\circ} \mathrm{F}$.

bimited by steam availablity at 150 psig.

'Limited by diffuser temperature limits. 
Operational Altitude Corridor
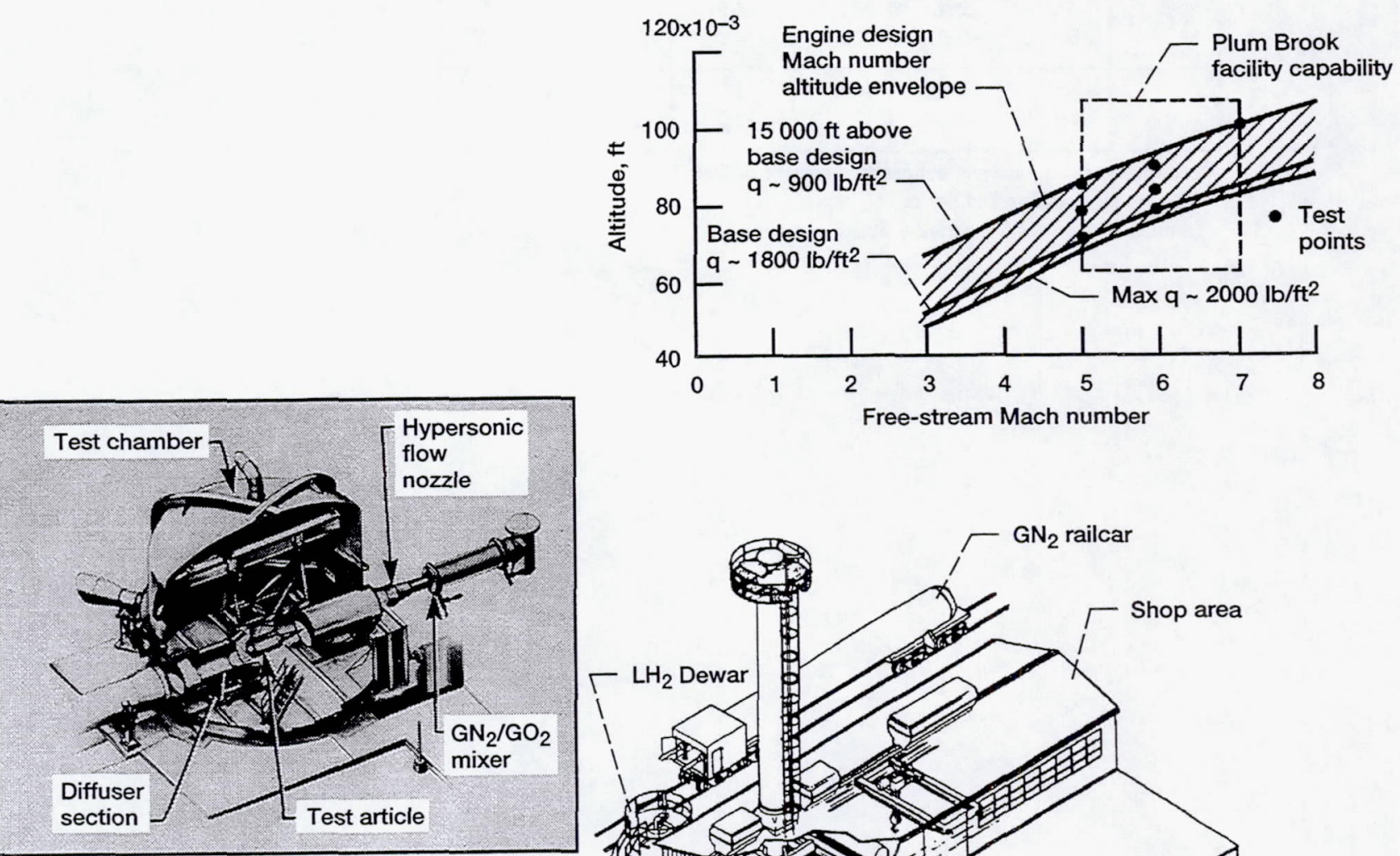

Enlarged View of Test Chamber
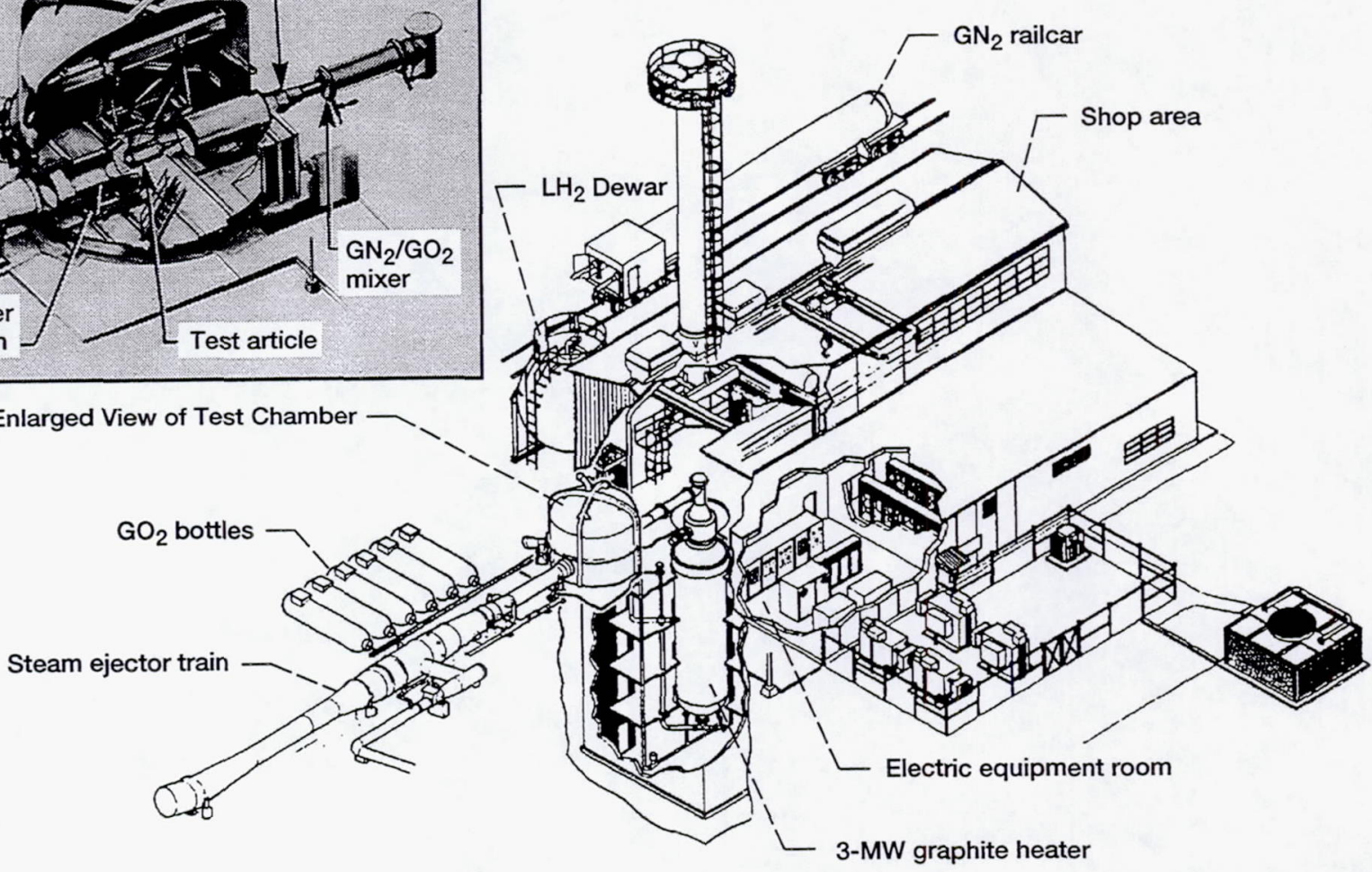

Figure 1.-Cutaway view of hypersonic tunnel facility (HTF). 


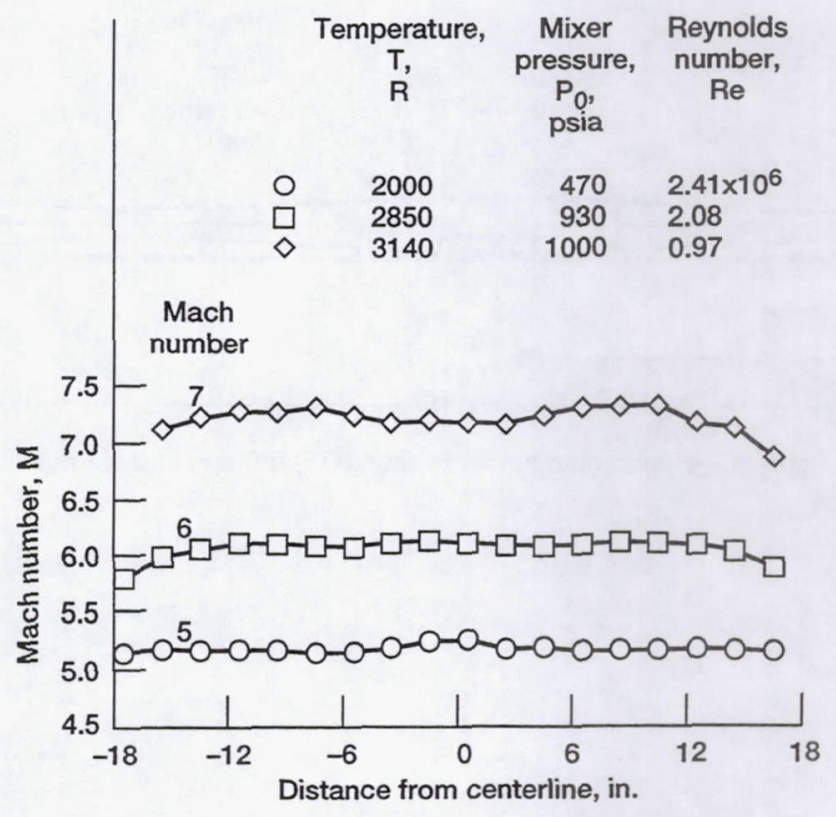

Figure 2.-Hypersonic tunnel facility nozzle calibrations.

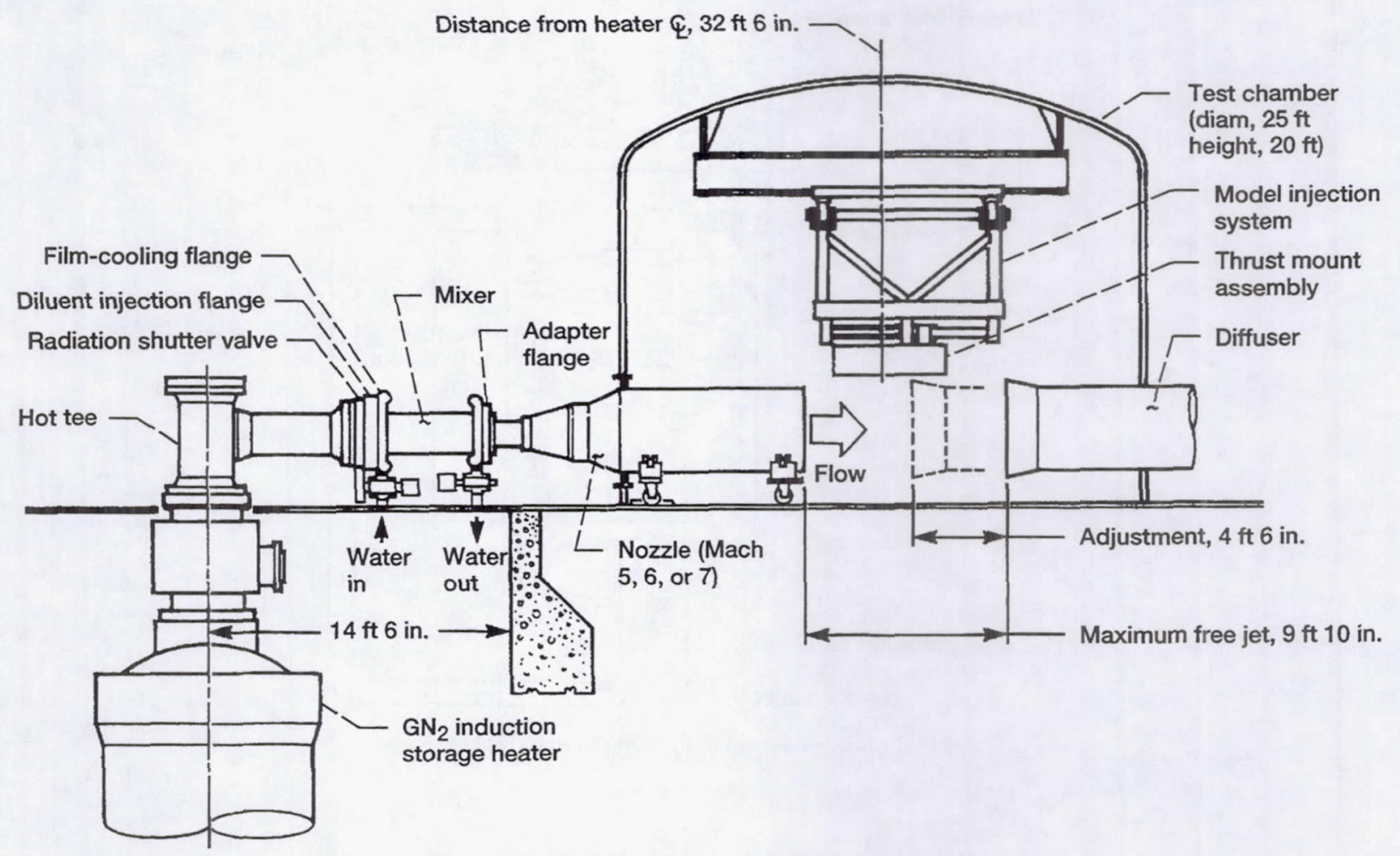

Figure 3.-Hypersonic tunnel facility (HTF) hot train and test chamber. 


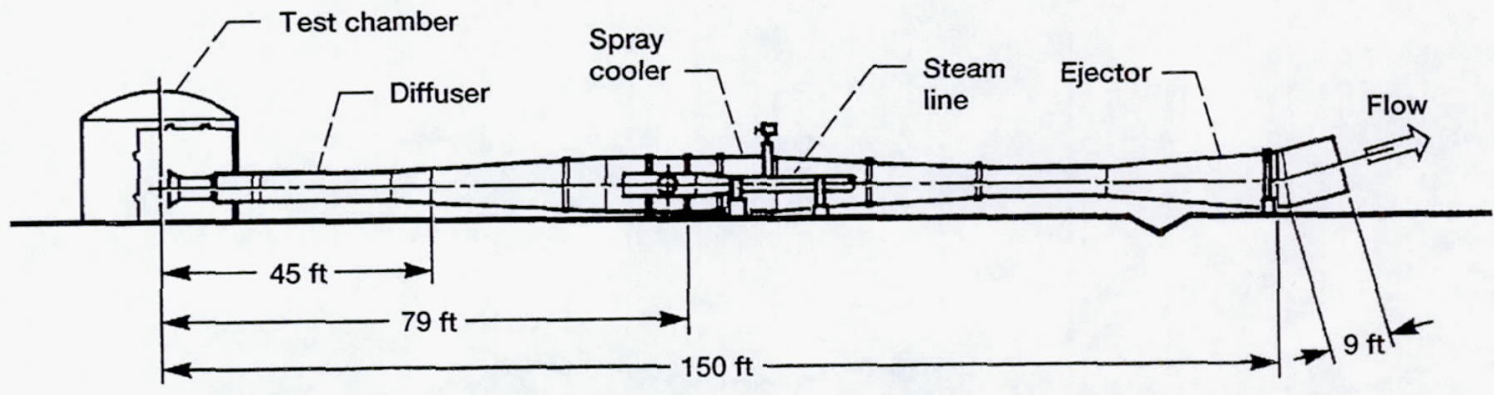

Figure 4.-Hypersonic tunnel facility (HTF) diffuser and ejector.

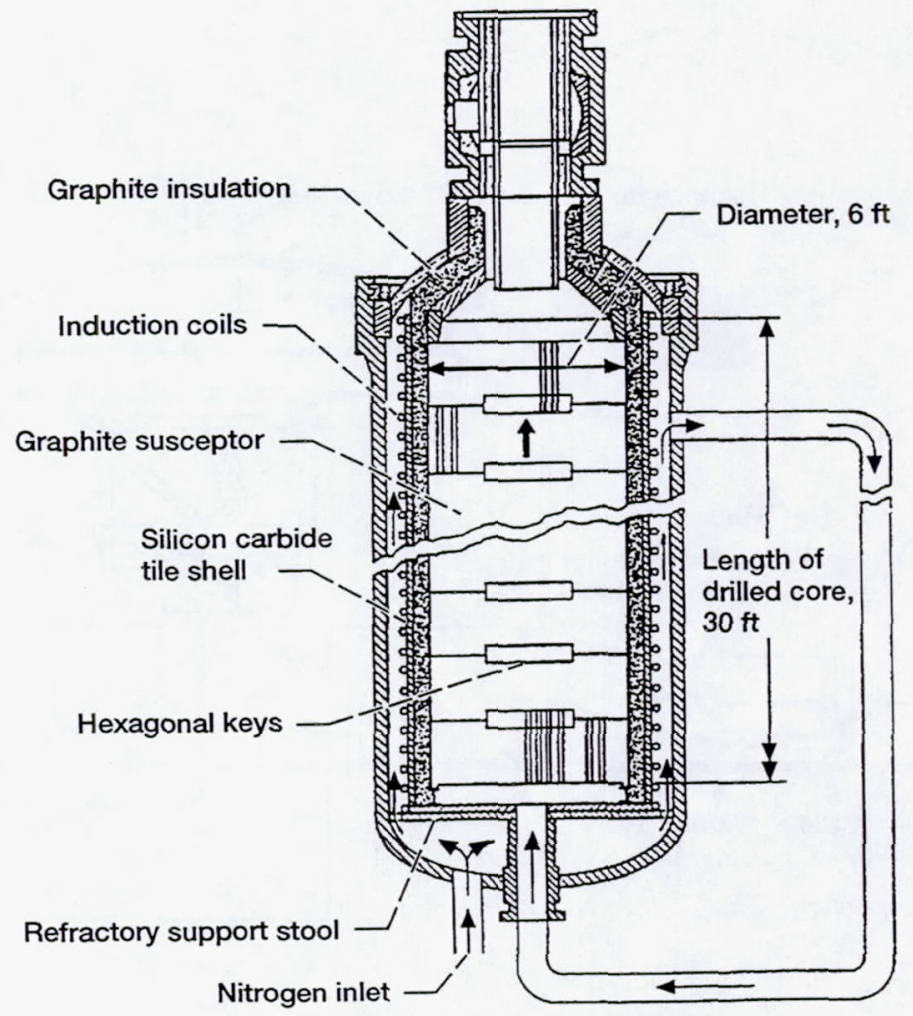

Figure 5.-Nitrogen induction storage heater. 


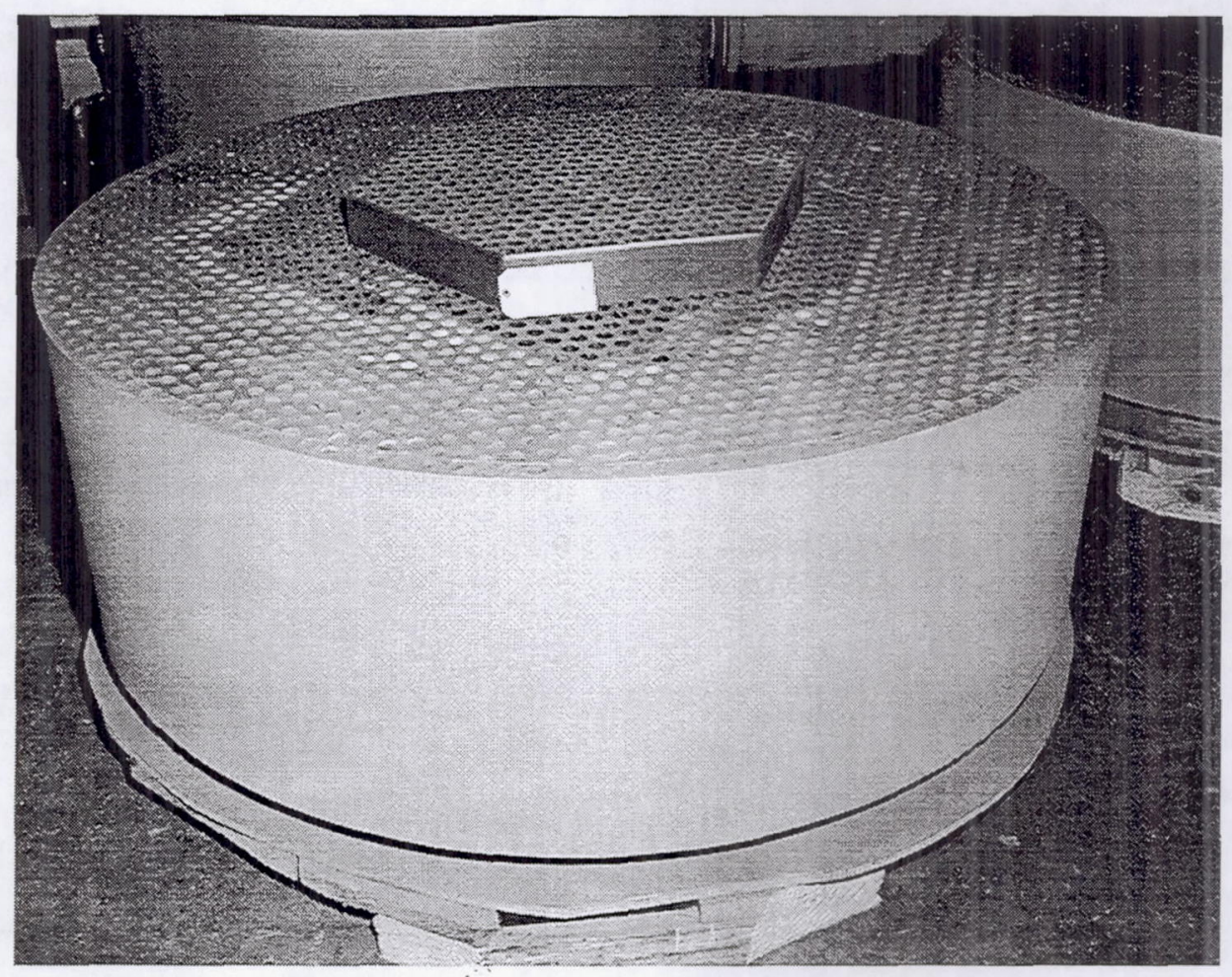

Figure 6.-Graphite block from induction storage heater.

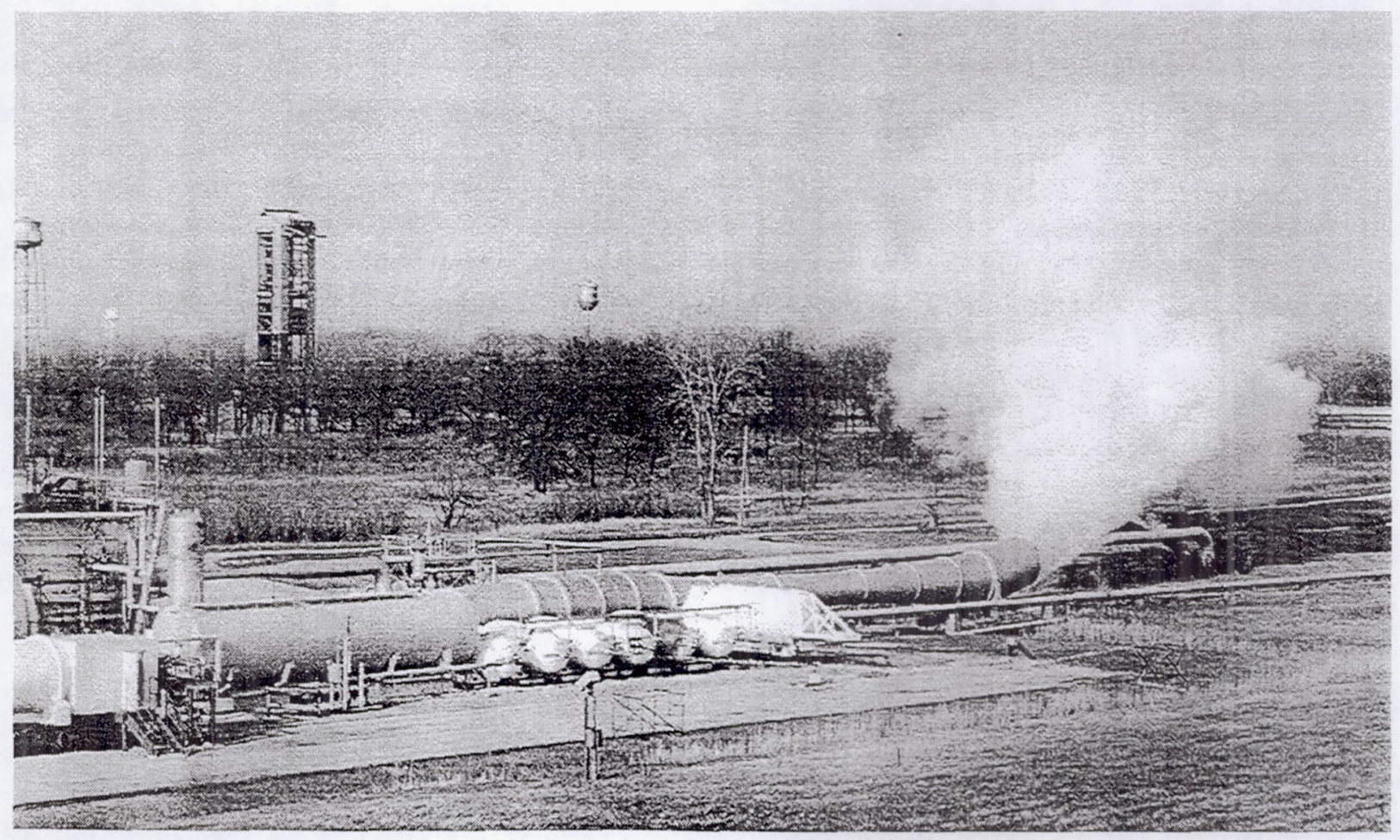

Figure 7.-HTF steam ejector in operation during integrated systems test on May 25, 1994. 
Public reporting burden for this collection of information is estimated to average 1 hour per response, including the time for reviewing instructions, searching existing data sources, gathering and maintaining the data needed, and completing and reviewing the collection of information. Send comments regarding this burden estimate or any other aspect of this collection of information, including suggestions for reducing this burden, to Washington Headquarters Services, Directorate for information (0)

\begin{tabular}{|l|l|l|}
\hline 1. AGENCY USE ONLY (Leave blank) & $\begin{array}{r}\text { 2. REPORT DATE } \\
\text { January } 1995\end{array}$ & $\begin{array}{r}\text { 3. REPORT TYPE AND DATES COVERED } \\
\text { Technical Memorandum }\end{array}$
\end{tabular}

4. TITLE AND SUBTITLE

Operating Capability and Current Status of the Reactivated NASA Lewis

Research Center Hypersonic Tunnel Facility
5. FUNDING NUMBERS

WU-505-70-62

6. AUTHOR(S)

Scott R. Thomas, Charles J. Trefny, and William D. Pack

7. PERFORMING ORGANIZATION NAME(S) AND ADDRESS(ES)

National Aeronautics and Space Administration

Lewis Research Center

Cleveland, Ohio 44135-3191

8. PERFORMING ORGANIZATION REPORT NUMBER

E-9294

9. SPONSORING/MONITORING AGENCY NAME(S) AND ADDRESS(ES)

10. SPONSORING/MONITORING AGENCY REPORT NUMBER

National Aeronautics and Space Administration

Washington, D.C. 20546-0001

NASA TM-106808

AIAA-95-6146

\section{SUPPLEMENTARY NOTES}

Prepared for the Sixth International Aerospace Planes and Hypersonics Technologies Conference sponsored by the

American Institute of Aeronautics and Astronautics, Chattanooga, Tennessee, April 3-7, 1995. Responsible person, Scott R. Thomas, organization code 2701, (216) 433-8713.

12a. DISTRIBUTIONAVAILABILITY STATEMENT

Unclassified - Unlimited

Subject Category 09

This publication is available from the NASA Center for Aerospace Information, (301) 621-0390.

13. ABSTRACT (Maximum 200 words)

The NASA Lewis Research Center's Hypersonic Tunnel Facility (HTF) is a free-jet, blowdown propulsion test facility that can simulate up to Mach-7 flight conditions with true air composition. Mach-5, -6, and -7 nozzles, each with a 42 -in. exit diameter, are available. Previously obtained calibration data indicate that the test flow uniformity of the HTF is good. The facility, without modifications, can accommodate models approximately $10 \mathrm{ft}$ long. The test gas is heated using a graphite core induction heater that generates a nonvitiated flow. The combination of clean-air, large-scale, and Mach-7 capabilities is unique to the HTF and enables an accurate propulsion performance determination The reactivation of the HTF, in progress since 1990, includes refurbishing the graphite heater, the steam generation plant, the gaseous oxygen system, and all control systems. All systems were checked out and recertified, and environmental systems were upgraded to meet current standards. The data systems were also upgraded to current standards and a communication link with NASA-wide computers was added. In May 1994, the reactivation was complete, and an integrated systems test was conducted to verify facility operability. This paper describes the reactivation activities, the facility status, the operating capabilities, and specific applications of the HTF.

\begin{tabular}{|c|c|c|}
\hline \multicolumn{3}{|l|}{ 14. SUBJECT TERMS } \\
\hline \multicolumn{3}{|c|}{ Hypersonic test facilities; Hypersonic propulsion; Vitiation; Scramjet propulsion } \\
\hline $\begin{array}{l}\text { 17. SECURTY CLASSIFICATION } \\
\text { OF REPORT } \\
\text { Unclassified }\end{array}$ & $\begin{array}{l}\text { 18. SECURITY CLASSIFICATION } \\
\text { OF THIS PAGE } \\
\text { Unclassified }\end{array}$ & $\begin{array}{l}\text { 19. SECURITY CLASSIFICATION } \\
\text { OF ABSTRACT } \\
\text { Unclassified }\end{array}$ \\
\hline
\end{tabular}

